\title{
水素チャージ下における高張力鋼板の破壊および 拡散性水素に及ぼすひずみ速度の影響
}

\author{
北原 学 $^{1}{ }^{*}$, 辻 彩 $^{1)}$, 浅田崇史 ${ }^{1)}$, 鈴木智博 ${ }^{1)}$, 堀川敬太郎 ${ }^{2)}$, 小林秀敏 ${ }^{2)}$ \\ 1) 株式会社豊田中央研究所材料・プロセス 1 部 \\ 2) 大阪大学大学院 基礎工学研究科 機能創成専攻
}

Influence of Strain Rate on Fracture Characteristics and

Diffusible Hydrogen of High Tensile Steel under Hydrogen Charging

\author{
Gaku Kitahara ${ }^{1)}$, Aya Tsuji ${ }^{1}$, Takashi Asada ${ }^{1)}$, Tomohiro Suzuki ${ }^{1)}$, \\ Keitaro Horikawa ${ }^{2)}$ and Hidetoshi Kobayashi ${ }^{2)}$ \\ 1) Toyota Central R\&D Labs., Inc., Material \& Processing Dept. I \\ 2) Osaka University, Graduate School of Engineering Science, Department of Mechanical Science \\ and Bioengineering, Division of Nonlinear Mechanics
} $\begin{array}{ll}\text { *責任著者(Corresponding Author) } & \begin{array}{l}\text { T 480-1192 長久手市横道 41-1(41-1 Yokomichi, Nagakute, 480-1192, Japan) } \\ \text { Email: gaku-k@mosk.tytlabs.co.jp }\end{array}\end{array}$

\begin{abstract}
Hydrogen embrittlement susceptibility is known to vary with decreasing strain rate. In this study, influence of strain rate on ductility, fracture characteristics and diffusible hydrogen in high tensile steel sheet under hydrogen charging was investigated using the tensile test by changing strain rate, fractography and thermal desorption spectroscopy (TDS). The ductility was lowered as strain rate decreased. Conversely, hydrogen embrittlement was not observed for the high strain rate with the magnitude in the order of $10^{-3} / \mathrm{s}$. The specimen with lowered ductility presented quasi-cleavage fracture and intergranular fracture. In this specimen, the faster the strain rate was, the wider and shallower the brittle fracture was distributed surrounding the test piece. On the other hand, the brittle fracture spreading to the inside was locally observed as the strain rate became slower. TDS revealed that the variation of ductility with change in strain rate depends on the hydrogen trapping sites and the amount of hydrogen trapped in dislocations and grain boundaries.
\end{abstract}

Key words : high tensile steel sheet, hydrogen embrittlement, strain rate, diffusible hydrogen, thermal desorption spectroscopy (TDS), stress, hydrogen trapping site

\section{1. 緒}

\section{言}

高強度鋼の水素脆化特性について陰極チャージ法など により水素を導入し, 種々の引張試験による評価 ${ }^{1-13)}$ が検討されている. 水素脆化評価の試験コストの観点か ら, 短時間で実施可能な通常の引張試験法 (CSRT : Conventional Strain Rate Technique $)^{2)-7)}$ による評価が望 ましいが, 鋼材によっては低ひずみ速度法 (SSRT : Slow Strain Rate Technique)の試験結果と必ずしも一致してい ない ${ }^{5)}$.

一般に水素脆化特性にはひずみ速度依存性があり ${ }^{14)}$, ひずみ速度が遅くなると破断ひずみが減少する ${ }^{15), 16)}$. これは, SSRTのようにゆっくりと塑性変形する場合で は水素拡散が転位の移動に追従でき, 水素トラップおよ び転位 - 水素の相互作用が大きいが, CSRTのように早 く塑性変形する場合では転位の移動が高速であり水素の 拡散が追従できず，転位 - 水素の相互作用が小さいた め, 水素脆化感受性が低い ${ }^{5)}$ と考えられているが，未だ 不明な点が多い.

そこで本研究では, 市販のマルテンサイト系高張力鋼 板を用い, 水素チャージ下でひずみ速度を変化させたと きの水素脆化特性の評価を行った. その際, 種々のひず み速度で試験した試験片の昇温脱離分析 (TDS : Thermal Desorption Spectroscopy)の結果から水素トラップサイ
トおよび拡散性水素量について評価した。両者の結果を 比較することで水素脆化特性に及ぼすひずみ速度の影響 について拡散性水素の観点から考察した。

\section{2. 実 験 方 法}

\section{1 供試材}

供試材には，市販のマルテンサイト系 $1400 \mathrm{MPa}$ 級高 張力鋼板を使用した。ひずみゲージを用いて大気中で測 定した応力 -ひずみ曲線を Fig. 1 に，材料の化学成分を

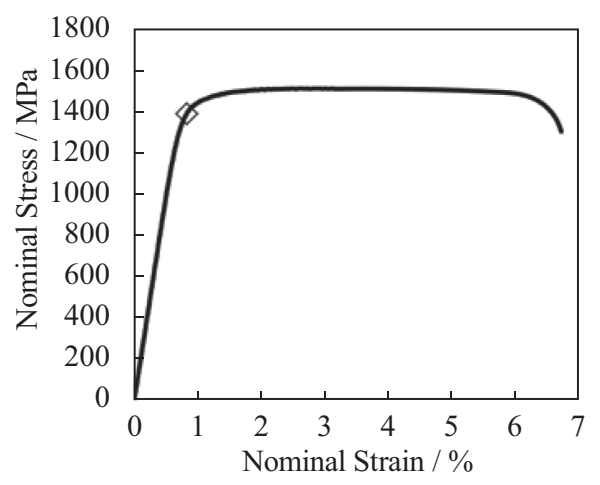

Fig. 1 Nominal stress-nominal strain curve in air. $\diamond$ indicates the stress within the uniform plastic deformation range. In this work, tensile test was carried out untill that stress and fracture. 
Table 1 Chemical composition (mass\%).

\begin{tabular}{cccccccccc}
\hline $\mathrm{C}$ & $\mathrm{Si}$ & $\mathrm{Mn}$ & $\mathrm{P}$ & $\mathrm{S}$ & $\mathrm{Cr}$ & $\mathrm{Al}$ & $\mathrm{Ti}$ & $\mathrm{V}$ & $\mathrm{Nb}$ \\
\hline 0.17 & 0.49 & 1.58 & 0.010 & 0.002 & 0.03 & 0.042 & 0.005 & 0.008 & 0.013 \\
\hline
\end{tabular}

Table 1 に示す. Fig. 1 が示すように本供試材は耐力以降, あまり応力が上がらない, 加工硬化しにくい材料である. また, 図中の〉は均一塑性変形範囲内の応力 $(1389 \mathrm{MPa})$ であり，定荷重試験を本応力に設定し実施したときに拡 散性水素が多く導入された ${ }^{17)}$.

\section{2 水素脆化特性に及ぼすひずみ速度の影響評価}

水素脆化特性を評価するために, Fig. 2 に示す装置を 用いて水素チャージ下でひずみ速度を変えて引張試験を 実施した。

Fig. 3 に試験片形状を示す。機械的特性評価では厚さ $1 \mathrm{~mm}$ の試験片を使用した。試験片は機械加工で製作 し，＃800のエメリー紙により表面研磨を行った。ま た, 試験片のチャック部に導線をスポット溶接し, 平行 部を除きマスキングテープおよびゴムマスキングにて絶 縁防食処理を行った。

水素チャージについては, 溶液に $3 \% \mathrm{NaCl}$ 水溶液を 使用し, 電流密度を $1 \mathrm{~mA} / \mathrm{cm}^{2}$ として陰極電解法により 実施した.Fig. 2 のように槽内に白金䇴(対極)を配置 し，ガルバノスタット(北斗電工製，HA-151B)を用い て，二電極式で水素チャージを実施した。槽内には，試 験片 1 本 (露出面積 : $1.8 \mathrm{~cm}^{2}$ ) に対し, $1000 \mathrm{ml}$ の溶液を 入れて試験を行った。

引張試験は, Table 2 に示す条件でひずみ速度を変化 させて実施した。条件 $\mathrm{A} 1$ は比較として大気中で条件 D と同じひずみ速度で実施した試験である。また，条件 $\mathrm{B} ， \mathrm{C} ＼textrm{D}$ および $\mathrm{E}$ の順でひずみ速度を遅くした。なお， 条件 B は一般に CSRT で実験されているのと同等のひず み速度である ${ }^{2-7)}$. 引張試験前に水素を試験片内に均一 に導入する目的で 16 時間以上のプレ水素チャージを実 施した．引張試験中も水素チャージを継続した．鋼中の 拡散性水素を脱離させないために破断直後に水素チャー ジの停止, 試験片の取り出しおよび切断を行い, 水素分 析を実施するまで液体窒素中に保存した。なお，水素 チャージ停止後の試験片の取り出しおよび切断において 大気中に置かれた時間は各 5 分以内であった.

また，破断後の試験片については走査型電子顕微鏡 (SEM : Scanning Electron Microscope, 日立ハイテク) ロジーズ製，SU3500）による破面形態観察と次節で述べ る水素分析を実施した。

\section{3 拡散性水素に及ぼすひずみ速度の影響評価}

種々のひずみ速度で引張試験したときの拡散性水素量 および水素存在状態を解析するためにTDS スペクトル を測定した。

引張試験にて破断させた試験片については破面を含むよ うに平行部を切断し, 半導体センサー型ガスクロマトグラ フィー(GC : Gas Chromatography, FIS 製, SGHA-P2) により水素分析を実施した。測定条件は $100 \mathrm{ml} / \mathrm{min} の$ 流速の $\mathrm{Ar}$ ガス気流中で室温から $200^{\circ} \mathrm{C}$ まで $2^{\circ} \mathrm{C} / \mathrm{min}$ で 昇温し，TDS スペクトルを得た。なお，測定温度範囲内

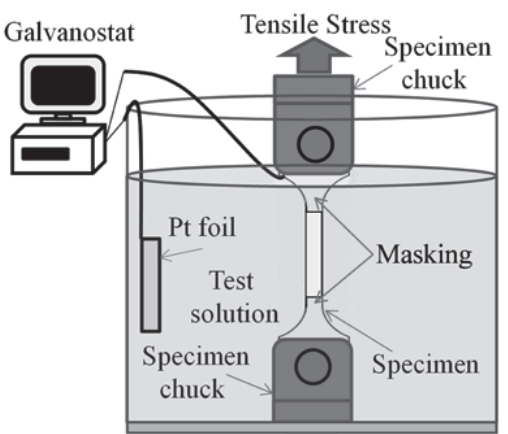

Fig. 2 Experimental apparatus for SSRT with hydrogen charging in test solution.

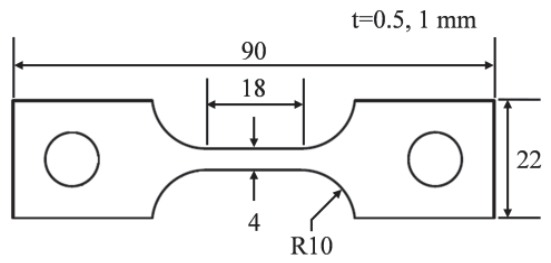

Fig. 3 Specimen dimension.

Table 2 Experimental conditions.

\begin{tabular}{|c|c|c|}
\hline Specimen ID. & Environment & Strain rate $/ \mathrm{s}^{-1}$ \\
\hline A1 & In air & $4.6 \times 10^{-6}$ \\
\hline A2 & & No Load \\
\cline { 1 - 1 } B & \multirow{4}{*}{$\begin{array}{c}\text { Hydrogen } \\
\text { charging }\end{array}$} & $1.9 \times 10^{-3}$ \\
C & $2.8 \times 10^{-5}$ \\
D & $4.6 \times 10^{-6}$ \\
\hline E & & $4.6 \times 10^{-7}$ \\
\hline
\end{tabular}

に見られたピークの積分值を拡散性水素量とした.

水素存在状態解析を実施するため, 佐藤らの報告 ${ }^{18)}$ に 倣い，2.2 節と同形状であるが，板厚を $0.5 \mathrm{~mm}$ とした 試験片で引張試験し，TDS スペクトルを測定した。その 際, ひずみ速度および水素チャージ条件は 2.2 節に示し た条件と同様であるが，同一応力，すなわち，Fig. 1 中 の〉で示した応力 $(1389 \mathrm{MPa})$ で引張試験を停止させ た。これは拡散性水素に及ぼす破面部近傍の格子欠陥量 の増加の影響を除去するため，および塑性変形量を同一 にすることで, 塑性変形に伴う転位や空孔の増加の影響 を除去にするためである，水素分析には，高周波加熱型 昇温脱離分析装置(電子科学製, IH-TDS1700)を使用した. 測定条件は，高真空中で $-50^{\circ} \mathrm{C}$ から $200^{\circ} \mathrm{C}$ まで $2^{\circ} \mathrm{C} / \mathrm{min}$ で昇温し，TDSスペクトルを得た。なお，予備検討によ り板厚を $0.5 \mathrm{~mm}$ にした試験片では拡散性水素量が少な く, GC では分解能が不足し, 十分に検出できなかった ために高周波加熱型TDSによる分析を実施した。 


\section{3. 実験結果および考察}

\section{1 機械的特性}

Fig. 4 に種々のひずみ速度で引張試験を実施したとき の応力 - 変位線図を示す. 図中には水素チャージの有無 を比較するために大気中 (条件 A1) で引張試験を実施し た結果を併せて示す。いずれのひずみ速度においても塑 性変形後に破断した，条件 B では大気中と同等の伸びが 得られたが，ひずみ速度を遅くするほど，伸びが減少し た.

Fig. 5 に大気中 (条件 A1)の試験結果で規格化した最大 応力 (Fig. 5(a))，伸び (Fig. 5(b)) および絞り (Fig. 5(c)) のひずみ速度依存性を示す。今回の試験誤差を図中に示 したが，最大で $7 \%$ 程度と誤差は少なかった。最大応力 はすべてのひずみ速度で大気中とほぼ同等であった。伸 びはひずみ速度が速い条件 B では大気中と同等であった が，ひずみ速度を遅くするほど，伸びが減少した．絞り

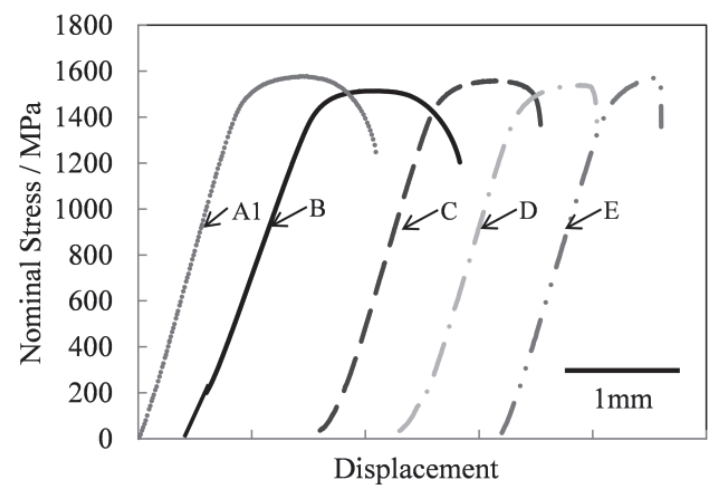

Fig. 4 Nominal stress-displacement curves. A1, B, C, D and E indicate specimen ID (see Table 2).

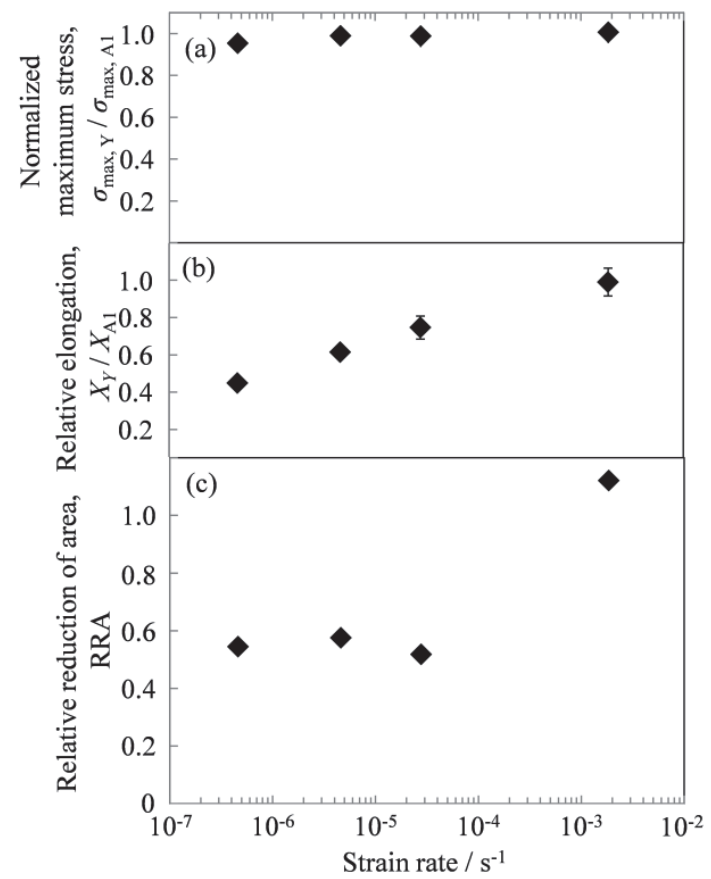

Fig. 5 Relationship between (a) normalized maximum stress $\left(\sigma_{\max , \mathrm{Y}} / \sigma_{\max , \mathrm{A} 1}\right),(\mathrm{b})$ relative elogaton $\left(X_{\mathrm{Y}} / X_{\mathrm{A} 1}\right),(\mathrm{c})$ relative reduction of area (RRA) and strain rate.
はひずみ速度が速い条件 B では大気中と同等であった が, 条件 C 以下のひずみ速度では大きく減少し，ほほ一 定となった。

\section{2 破面観察結果}

Fig. 6 に大気中 (条件 A1)で試験し，破断させた試験片 の SEM による破面観察結果を示す。条件 A1 では試験 片の中心付近に圧延の影響と考えられる圧延方向への亀 裂が見られたものの，ほぼ全面が延性破壊を示すディン プル破面を呈していた。

Fig. 7 に条件 B で試験し，破断させた試験片の破面観 察結果を示す。条件 A1 と同様にほぼ全面がディンプル 破面を呈しており，明暸な擬へき開破面および粒界破面 は見られなかった。

Fig. 8 に条件 C で試験し，破断させた試験片の破面観

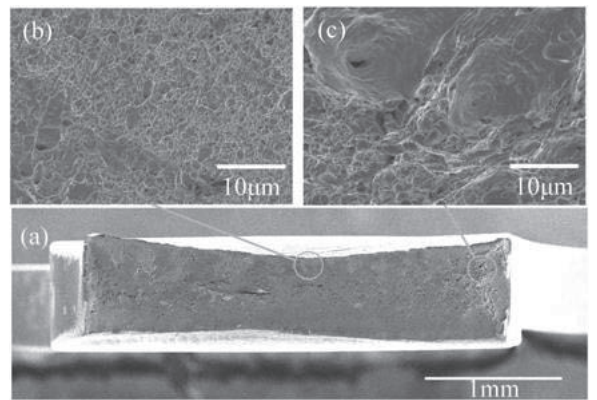

Fig. 6 SEM images of specimen A1. (a) General view, (b), (c) Enlarged images.

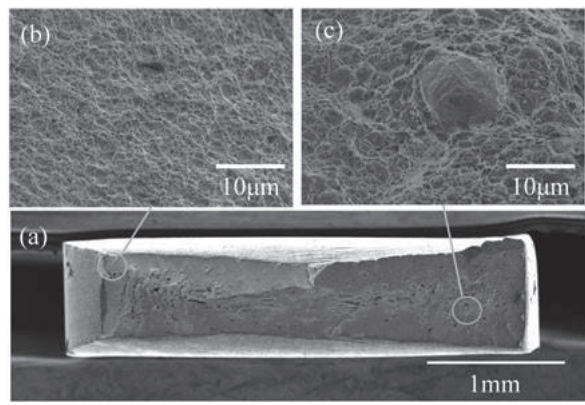

Fig. 7 SEM images of specimen B. (a) General view, (b), (c) Enlarged images.

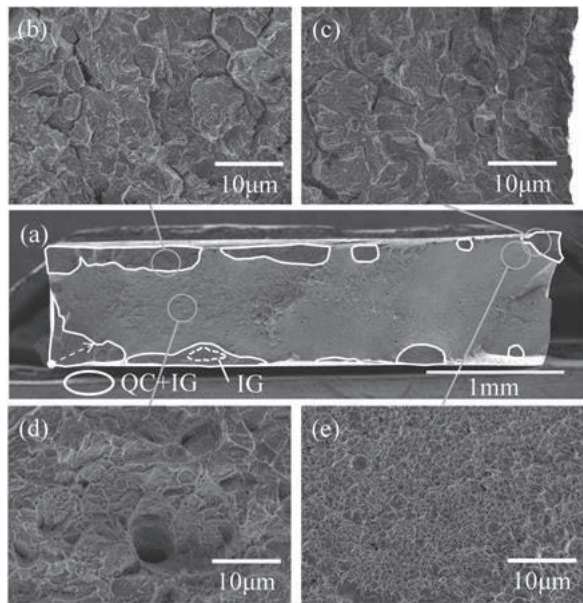

Fig. 8 SEM images of specimen C. (a) General view, (b)-(e) Enlarged images. 
察結果を示す．試験片端部に広く分布した脆性破面が見 られた．脆性破面は擬へき開破面(図中, QC)が主であっ たが，その中にわずかに粒界割れ(図中，IG）をしている 箇所が散見された。試験片内部はディンプル破面を呈し ていた.

Fig. 9 に条件 D で試験し, 破断させた試験片の破面観 察結果を示す．条件 C と同様に擬へき開破面を主とし, 粒界破面がわずかに観察される脆性破面(図中, QC+ IG)が見られた。条件 Cに比べ，脆性破面領域が内部ま で進展している様子が見られた。 また，(e)のようにディ ンプル破面であるものの窪みの部分に浅い破面が見られ た。

Fig. 10 に条件 E で試験し, 破断させた試験片の破面 観察結果を示す。条件 C および D と同様に擬へき開破 面(図中，QC) と粒界破面(図中，IG)を呈していた。ま た，条件 Cおよび $\mathrm{D}$ とは異なり，試験片の端部から内 部へ比較的広範囲に広がった脆性破面が 1 つと複数の小 さな破面が連なったような脆性破面が写真右側に偏在し て観察された。試験片内部については，他の試験片と同 様，ディンプル破面を呈していた。 また，(b)のように ディンプル破面でも窪みの部分が浅い破面が見られた.

Fig. 11 に脆性破面率および破壊起点部から脆性破面端

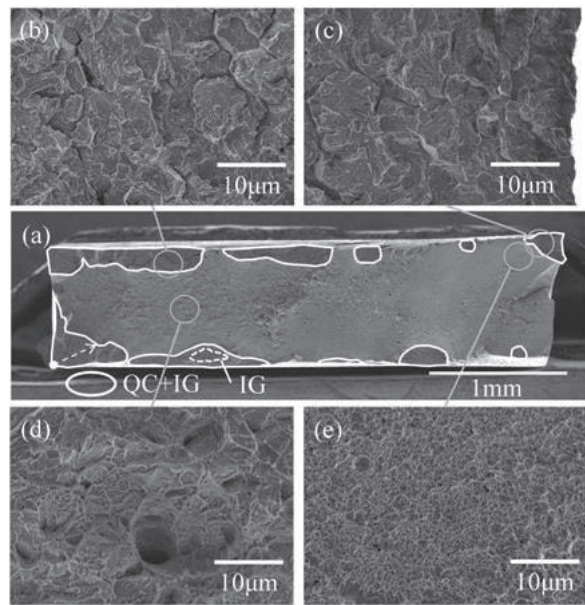

Fig. 9 SEM images of specimen D. (a) General view, (b)-(e) Enlarged images.
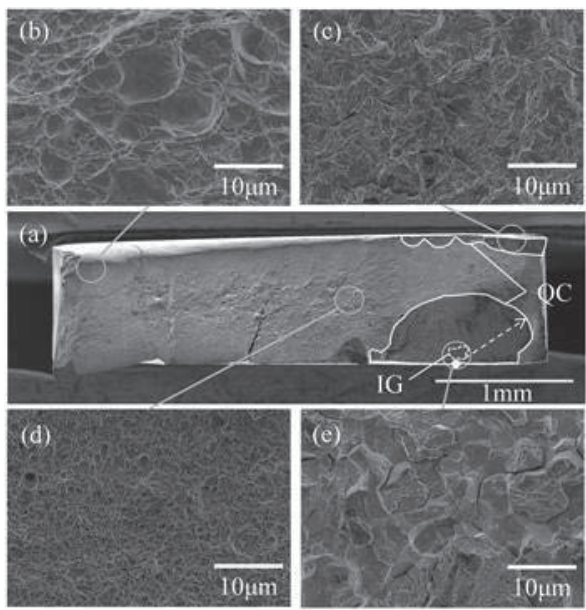

Fig. 10 SEM images of specimen E. (a) General view, (b)-(e) Enlarged images.
部までの最大長さ (各種破面観察結果上の点線矢印の長 さ)のひずみ速度依存性を示す。脆性破面率は条件 B 以 下のひずみ速度でほぼ一定であった。最大長さはひずみ 速度が遅くなるほど，大きくなることがわかった。ま た，ひずみ速度が比較的速い条件 Cでは，試験片周囲を 囲むように浅く広く脆性破面が分布しているのに対し て，ひずみ速度の遅い条件 D では条件 Cよりも脆性破 面が内部まで進展し, さらに遅い条件 $\mathrm{E} て ゙ は$ 脆性破面が 局所的に，かつ，さらに内部へ進展していた。

\section{3 水素分析結果}

Fig. 12 に破断後の試験片の TDS スペクトルを示す. 眓中には無負荷 (条件 A2) で水素チャージを行った試験 片のスペクトルも併せて示す．（a）はTDS スペクトルの 全体図，（b）は条件 A2，B および C の TDS スペクトル の拡大図である．横軸の温度は試験片から近傍の炉内温 度である。いずれのひずみ速度で試験を実施してもピー ク強度は条件 A2 に比べて大きかった．また，ひずみ速 度の速い条件 B ではピーク温度が高温側にシフトした。 ひずみ速度が条件 B よりも遅い条件ほど，ピーク温度が

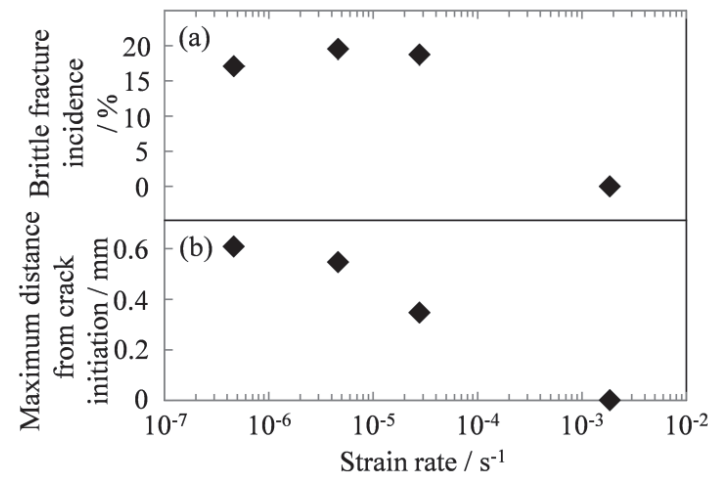

Fig. 11 Relationship between (a) brittle fracture incidence, (b) maximum distance from crack initiation and strain rate.

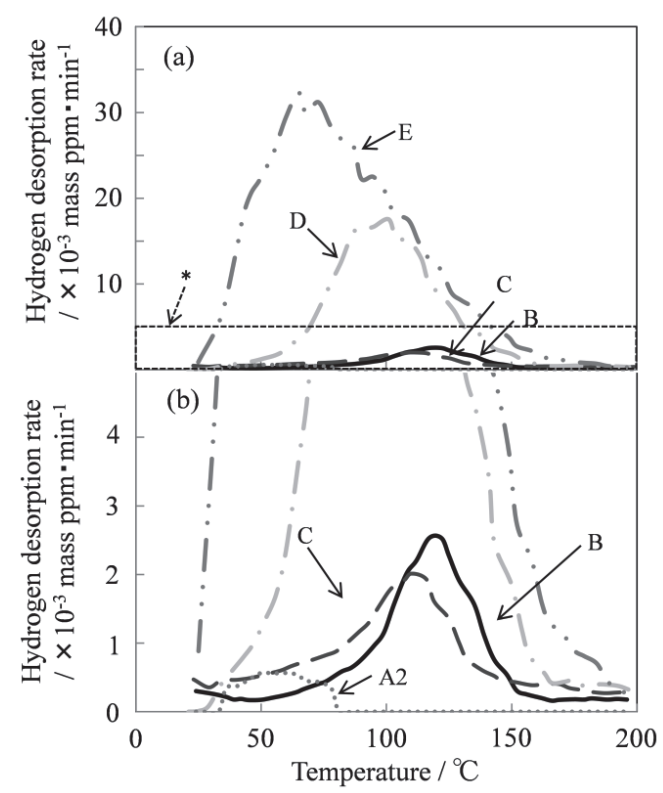

Fig. 12 TDS spectrums of the fractured specimen (B, C, D and E). A2 is the specimen charged with hydrogen at no load. (a) General view (b) Enlarged figure of the part* . 
低温側にシフトし, 条件 $\mathrm{A} 2$ と同様のピーク温度となっ た。

Fig. 13 に無負荷 (条件 A2) および条件 B から E とひず み速度を遅くし，1389 MPa まで負荷した試験片の TDS スペクトルを示す。横軸の温度は試験片の温度である. 条件 $\mathrm{A} 2$ では約 $20^{\circ} \mathrm{C}$ にピーク温度を示した. ひずみ速度 の速い条件 $\mathrm{B}$ では約 $70^{\circ} \mathrm{C}$ にピークを持ち, 破断後の試 験片と同様，高温側にシフトした。このとき，条件 $\mathrm{A} 2$ で見られた約 $20^{\circ} \mathrm{C}$ の低温側の位置にスペクトルは見られ なかった。一方, 条件 B よりもひずみ速度を遅くするほ ど，低温側にピークシフトしていった。 上記の条件 D お

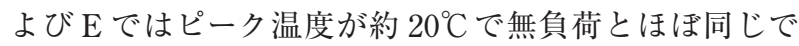
あった。ひずみ速度を遅くした場合でのピークシフトも 破断後の試験片と同様の傾向が見られた。 また，条件 $\mathrm{C}, \mathrm{D}$ および $\mathrm{E}$ のスペクトルは大きく対称性が崩れたス ペクトル形状になっており，高温側にテールを引いた形 状になっていた。このスペクトルについては条件 A2 で 見られた低温側のピークと条件 Bで見られた高温側の ピークが重畳した形になっていると考えられる。 また, 条件 A2 のスペクトルに比べ，引張試験による負荷を実 施することによりピーク強度が大きくなったと考えられ る.

なお，破断後の試験片のスペクトルと $1389 \mathrm{MPa}$ まで 負荷した試験片のスペクトルでは, いずれのスペクトル においても $1389 \mathrm{MPa}$ まで負荷した試験片の方がピーク温 度は低温であり，かつ明瞭なピークが見られた。 $1389 \mathrm{MPa}$ まで負荷した試験片でピークが低温となったのは試験片 厚さおよび低温からTDSを実施したためと考えられる。 また, 高周波加熱型 TDS の水素の検出分解能が非常に 高いため, 水素量が少なくても明瞭なピークが見られた と考えられる.

Fig. 14 に破断後の試験片の, Fig. 15 に $1389 \mathrm{MPa}$ まで 負荷した試験片の TDS スペクトルを測定した温度範囲 で積分し, 拡散性水素量を求めた結果を示す. 条件 B と Cでは, いずれの試験片でも拡散性水素量はほぼ同量で あった，一方，よりひずみ速度を遅くした条件 D および $\mathrm{E}$ では, 条件 $\mathrm{B}$ および $\mathrm{C}$ より多くの拡散性水素量が導入 されていた．また，いずれの試験片でもひずみ速度が遅 いほど, 拡散性水素量は増加したが, 破断後の試験片の 方が拡散性水素が増加が顕著であった。

Fig. 16 にひずみ速度を変化させたときに導入された拡

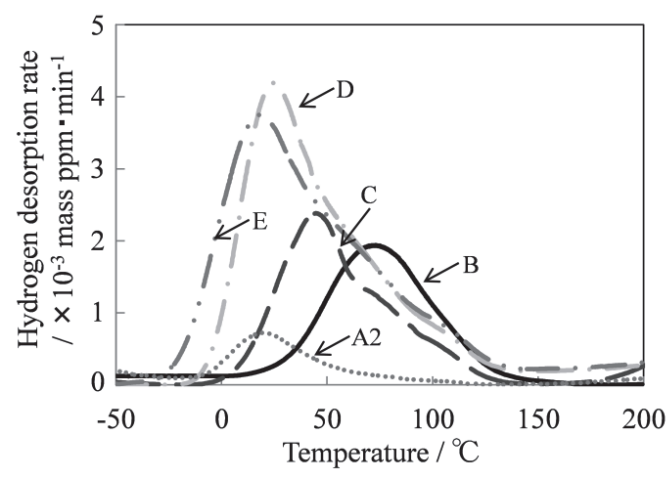

Fig. 13 TDS spectrums of the specimen loaded until $1389 \mathrm{MPa}$ (B, C, D and E). A2 is the specimen charged with hydrogen at no load.

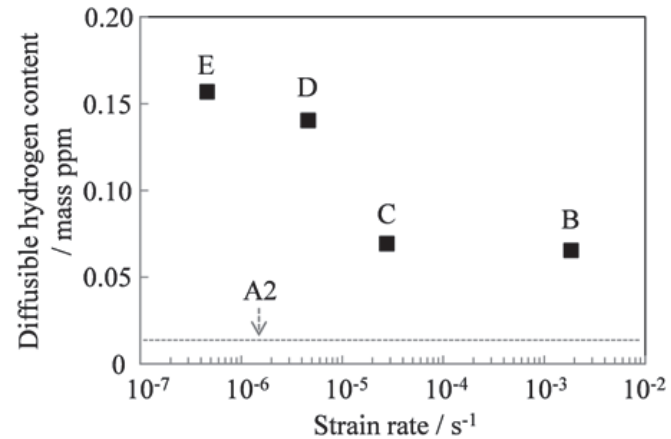

Fig. 14 Relationship between diffusible hydrogen content of fractured specimen and strain rate. A2 is the specimen charged with hydrogen at no load.

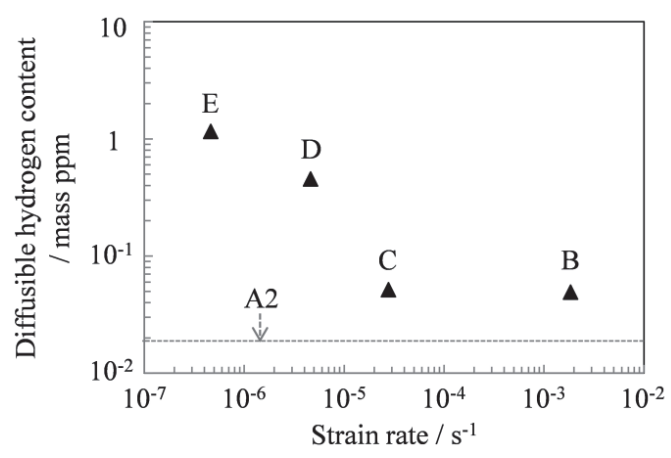

Fig. 15 Relationship between diffusible hydrogen content of specimen loaded until $1389 \mathrm{MPa}$ and strain rate. A2 is the specimen charged with hydrogen at no load.

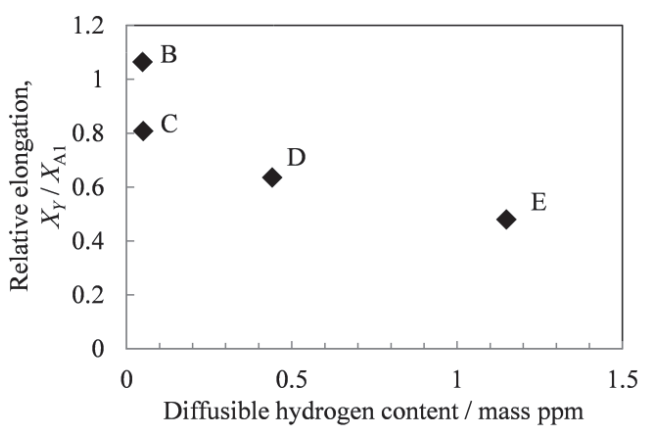

Fig. 16 Relationship between relative elongation and diffusible hydrogen content.

散性水素量と延性の関係を示す．ひずみ速度が速い条件 $\mathrm{B}$ では拡散性水素を有するのにも関わらず，大気中と同 様の延性を有した。すなわち，本供試材では， $0.05 \mathrm{ppm}$ 程度の拡散性水素量では CSRT 相当以上のひずみ速度で 引張変形を与えても機械的特性はほとんど変化しないこ とが示唆された。ところが，ひずみ速度を遅くした条件 $\mathrm{C}$ では条件 B とほぼ同量の拡散性水素量であるのに関わ らず，延性が低下した。また，条件 Cよりもさらにひず み速度の遅い条件 D, E において, ひずみ速度が遅いほ ど, 拡散性水素量が増加し, さらなる延性低下が生じた。

\section{4. 考察}

ここでは，ひずみ速度を変化させたときの延性，拡散 性水素および破面の関係について考察する。 
ひずみ速度が速い条件である条件 B では，塑性変形開 始から破断するまでの時間が数十秒以内と非常に短いた め, 外部からの水素侵入が少なく, 拡散性水素量が少な かったと考えられる。 また，Fig. 13 のTDS スペクトル は約 $70^{\circ} \mathrm{C}$ にピークを持つ対称性のよいスペクトルが現れ た。このスペクトルは他の条件に比べ，ピーク温度が高 いため, 他の条件とは水素トラップサイトが異なること を示唆している. TDSでは室温付近のスペクトルは転位 や結晶粒界に相当する水素 ${ }^{19)}$ と考えられているが，それ よりもピーク温度が高いため, 条件 B のスペクトルに相 当する水素は, 転位や結晶粒界よりも強く結合され, 脱 離しづらいトラップサイトにトラップされたと推測され る。すなわち, 脆化を担う転位や結晶粒界にトラップさ れた水素を奪ったため, 無害化され, 延性低下が見られ なかったと推測される。このときの水素トラップサイト の特定については今後の課題であり, SSRTで得られる 欠陥よりも陽電子寿命が小さい欠陥 $(450 \mathrm{ps} \text { 程度 })^{20)}$, 水 素 - 応力の相互作用によって生成される空孔クラスター ${ }^{19)}$ が挙げられるがいずれも脆化に寄与すると報告されてい るため, これらとは考えがたい. 本実験で得られた欠陥 を陽電子消滅法などの分析により特定し，活用できれば 耐水素脆化材料開発の一助になると思われる.

一方, 条件 Cでは拡散性水素量はほぼ同様であった

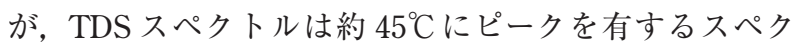

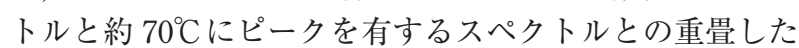
スペクトルになっていた。これは条件 B と比べるとひず み速度が遅いため, 条件 B で見られた結合の強いトラッ プサイトにトラップしきれなかった拡散性水素が転位な どの結合の弱い水素トラップサイトにも集積され, 脆化 し，延性低下が起きたと推察される。

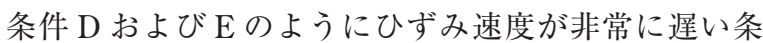
件では，TDSスペクトルにおいて $20^{\circ} \mathrm{C}$ 付近でピークを 有するスペクトル強度が大きく，そのピークに相当する 拡散性水素が多く検出された。このひずみ速度では変形 が遅いために引張変形中の水素チャージにより鋼中に侵 入した水素が塑性変形に伴う転位の移動に追従し, 転位 や結晶粒界などの水素トラップに多く集積したため, 脆 化し，より延性低下が起こったと考えられる。

また，破面については，下記のように考察する。

条件 B では前記の通り, 転位, 結晶粒界にトラップさ れた水素が存在しなかったために脆化せず, 擬へき開お よび粒界破面が見られなかったと考えられる，条件 Cで は脆性破面は試験片周囲を囲むように浅く広く見られ, 条件 D, E とひずみ速度を遅くすると破面が試験片内部 まで拡がり, 局所的に分布した。 これは, 下記の過程で 破壊が起こったためと考えられる。まず，鋼中の水素集 積した箇所である距離分だけ脆化し, き裂発生, 進展す る.しかし, 変形が速く, 水素の移動が変形およびそれ に伴うき裂進展に追従できないため, その距離を超えた 箇所では水素による脆化の影響が少なくなり, き裂の停 滞が起こる，そうすると，また別の水素集積が進んでい る箇所からき裂発生, 進展が起こる。この過程を幾重に も繰り返した後, 最終破断に至ると破壊メカニズムが推 測される. 条件 Cでは変形が非常に早いために水素が拡 散する距離が短く，条件 D ではよりひずみ速度が遅いた め, 水素による脆化の影響がより離れたところまで及
び，破面が内部まで拡がったと考えられる，条件 Eでは ひずみ速度が非常に遅く, 水素拡散がき裂進展にほぼ追 従できたために, 試験片周囲に広く分布することなく, 局所的で大きな脆性破面が見られたと考えられる。

以上より, ひずみ速度変化に伴う延性変化は引張試験 中の水素トラップサイトの変化や転位・結晶粒界にト ラップされた水素および拡散距離の変化に対応して起 こったと定性的に推定される。しかし，今回の試験で得 られた拡散性水素量および脆性破面に関するひずみ速度 の影響について, 定量的に考察するためには水素拡散係 数とひずみ量の関係 ${ }^{21,22)}$ および水素チャージ下におけ るき裂進展特性についての検討が必要と考えられ, これ らについては今後の課題である.

\section{5. 結}

\section{言}

市販の高張力鋼板を用いて，水素チャージ下でひずみ 速度を変化させたときの延性, 破面および拡散性水素の 評価を行った結果，以下の結論が得られた。

（1）ひずみ速度が速い場合 (条件 B)に延性の低下は見ら れなかった。このとき，ひずみ速度の遅い条件とは ピーク温度の異なる拡散性水素が検出され, 転位, 結晶粒界よりも結合の強いサイトに水素がトラップ され，無害化されたことが一因と推察される。

(2)ひずみ速度が遅い場合 (条件 C, D および $\mathrm{E})$, ひず み速度が遅いほど，延性低下が見られた。このとき， 転位と結晶粒界に相当するサイトにトラップされた 拡散性水素量が増加した。侵入した水素が転位, 結 晶粒界に集積されて脆化が促進されたと考えられる.

（3）破面観察の結果，ひずみ速度が遅く，延性低下した 試験片で擬へき開および粒界破面が確認された。ひ ずみ速度が速いと試験片周囲に脆性破面が広く浅く 分布し, ひずみ速度が遅いほど, 脆性破面が局所的 に内部まで拡がっていた。

(4)ひずみ速度変化に伴う延性変化は引張試験中の水素 トラップサイトの変化や転位・結晶粒界にトラップ された水素量および拡散距離の変化に対応して起 こったと推定される。

\section{参 考 文 献}

1) Y. Hagihara, C. Ito, N. Hisamori, H. Suzuki, K. Takai and E. Akiyama, Tetsu-to-Hagane, 94[6] pp.215-221(2008).

2) Y. Hagihara, C. Ito, D. Kirikae, N. Hisamori, H. Suzuki and K. Takai, Tetsu-to-Hagane, 95[6] pp.489-497 (2009)

3) Y. Hagihara, K. Shobu, N. Hisamori, H. Suzuki, K. Takai and K. Hirai, Tetsu-to-Hagane, 97[3] pp.143-151(2011).

4) T. Hojo, H. Waki and F. Nishimura, Tetsu-to-Hagane, 94[6] pp.215-221 (2008).

5) T. Chida, Y. Hagihara, E. Akiyama, K Iwanaga, S. Takagi, H. Onishi, M. Hayakawa, D. Hirakami and T. Tarui, Tetsuto-Hagane, 100[10] pp.1298-1305(2014).

6) S. Takagi, Y. Hagihara, T. Hojo, W. Urushihara and K. Kawasaki, Tetsu-to-Hagane, 100[10] pp.1315-1321(2014).

7) M. Wang, E. Akiyama and K. Tsuzaki, Mater. Sci. Eng. A, 398A, pp.37-46 (2005).

8) M. Wang, E. Akiyama and K. Tsuzaki, Scr. Mater., 53, pp.713-718(2005).

9) M. Wang, E. Akiyama and K. Tsuzaki, Corrs. Sci., 49, pp.4081-4097 (2005).

10) T. Kushida, H. Matsumoto, N. Kuratomi, T. Tsumura, F. Nakazato and T. Kudo, Tetsu-to-Hagane, 82[4] pp.297-302 (1996). 
11) S. Takagi, Y. Hagihara, T. Hojo, W. Urushihara and K. Kawasaki, Tetsu-to-Hagane, 100[10] pp.1315-1321(2014).

12) S. Yamazaki and T. Takahashi, Tetsu-to-Hagane, 83[7] pp.454-459(1997).

13) S. Takagi, T. Inoue, T. Hara, M. Hayakawa, K. Tsuzaki and T. Takahashi, Tetsu-to-Hagane, 86[10] pp.689-696(2000).

14) N. Ohtani, Tetsu-to-Hagane, 60 [2] pp.304-316(1974).

15) K. Sakai, M. Kiyoshige and K. Kita, J. Japan Inst. Met. Mater., 39[9] pp.944-951(1975).

16) K. Nakano, M. Kanao and T. Aoki, Tetsu-to-Hagane, 71[2] pp.258-259 (1985).

17) G. Kitahara, A. Tsuji, T. Asada, T. Suzuki, K. Horikawa and H. Kobayashi, Zairyo-to-Kankyo, 67, p.172 (2018).
18) Y. Sato, K. Fujita, H. Suzuki and K. Takai, Y. Hagihara, CAMP-ISIJ, 22, p.599 (2009).

19) K. Takai,Zairyo-to-Kankyo, 60, p.230 (2011).

20) Y. Sakiyama, T. Ohmura, K. Sugita, M. Mizuno, H. Araki and Y. Shirai, CAMP-ISIJ, 30, p.846(2017).

21) T. Asada, G. Kitahara, T. Suzuki and A.Tsuji, Trans. Jpn. Soc. Mech. Eng., 83, p.17-00012(2017).

22) Y. Huang, A. Nakajima, A. Nishikata and T. Tsuru, ISIJ Int., 43, pp.548-554(2003).

\section{要旨}

ひずみ速度を遅くすると水素脆化感受性が変化することが知られている. 本研究では高張力鋼板におけ る水素脆化に及ぼすひずみ速度依存性を明らかにするために，水素チャージ下でひずみ速度を変化させた 試験, 破面解析および昇温脱離分析を用いて, 延性, 破面および拡散性水素の関係を評価した。 その結 果，ひずみ速度が遅いほど延性低下したが，10 $10^{-3} / \mathrm{s}$ 台の速いひずみ速度で試験すると延性低下が認められ なかった，延性低下した試験片では擬へき開破面および粒界破面が見られ，ひずみ速度が速いとき，試験 片周囲に脆性破面が広く浅く分布し，ひずみ速度が遅くなるほど，脆性破面が局所的に内部まで見られ た. また, 昇温脱離分析からひずみ速度変化に伴う延性変化は水素トラップサイトや転位・結晶粒界にト ラップされた水素量によることを明らかにした.

キーワード 高張力鋼板, 水素脆化, ひずみ速度, 拡散性水素, 昇温脱離分析 (TDS), 応力, 水素卜 ラップサイト 